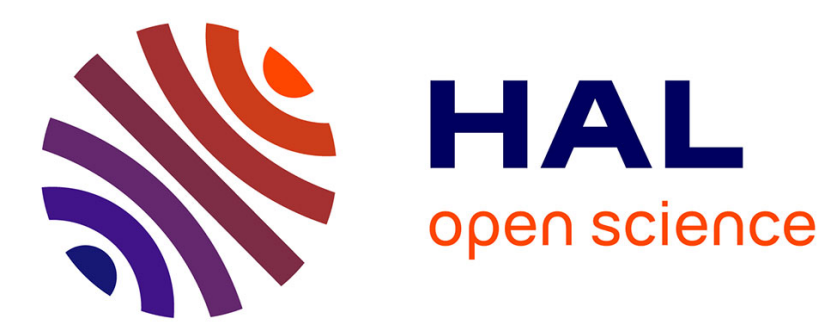

\title{
Influence of storage conditions on the functional properties of micellar casein powder
}

\author{
Sarah Nasser, Anne Moreau, Romain Jeantet, Alain Hédoux, Guillaume
}

Delaplace

\section{- To cite this version:}

Sarah Nasser, Anne Moreau, Romain Jeantet, Alain Hédoux, Guillaume Delaplace. Influence of storage conditions on the functional properties of micellar casein powder. Food and Bioproducts Processing, 2017, 106, 10.1016/j.fbp.2017.09.004 . hal-01619006

\section{HAL Id: hal-01619006 https://hal.science/hal-01619006}

Submitted on 26 May 2020

HAL is a multi-disciplinary open access archive for the deposit and dissemination of scientific research documents, whether they are published or not. The documents may come from teaching and research institutions in France or abroad, or from public or private research centers.
L'archive ouverte pluridisciplinaire HAL, est destinée au dépôt et à la diffusion de documents scientifiques de niveau recherche, publiés ou non, émanant des établissements d'enseignement et de recherche français ou étrangers, des laboratoires publics ou privés.

$$
\text { Copyright }
$$




\section{Accepted Manuscript}

Title: Influence of storage conditions on the functional properties of micellar casein powder

Authors: Sarah Nasser, Anne Moreau, Romain Jeantet, Alain Hédoux, Guillaume Delaplace

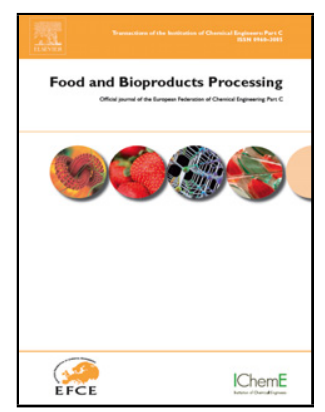

PII: S0960-3085(17)30119-0

DOI: https://doi.org/10.1016/j.fbp.2017.09.004

Reference: FBP 904

To appear in: Food and Bioproducts Processing

Received date: 3-5-2017

Revised date: 25-7-2017

Accepted date: 18-9-2017

Please cite this article as: Nasser, Sarah, Moreau, Anne, Jeantet, Romain, Hédoux, Alain, Delaplace, Guillaume, Influence of storage conditions on the functional properties of micellar casein powder.Food and Bioproducts Processing https://doi.org/10.1016/j.fbp.2017.09.004

This is a PDF file of an unedited manuscript that has been accepted for publication. As a service to our customers we are providing this early version of the manuscript. The manuscript will undergo copyediting, typesetting, and review of the resulting proof before it is published in its final form. Please note that during the production process errors may be discovered which could affect the content, and all legal disclaimers that apply to the journal pertain. 


\title{
Influence of storage conditions on the functional properties of micellar casein powder
}

\author{
Sarah Nasser ${ }^{\mathrm{a}, \mathrm{b}, \mathrm{c}, \mathrm{d}}$, Anne Moreau ${ }^{\mathrm{b}, \mathrm{c}}$, Romain Jeantet ${ }^{\mathrm{d}}$, Alain Hédoux ${ }^{\mathrm{b}, \mathrm{e}}$, Guillaume Delaplace $^{\mathrm{b}, \mathrm{c}}$ \\ a-Centre National Interprofessionnel de l'Economie Laitière, F-75009 Paris, France \\ b-Univ.Lille, CNRS, INRA, ENSCL, UMR 8207, UMET, Unité Matériaux et Transformations, F- \\ 59 000, Lille, France \\ c-INRA, UR 638, Processus aux Interfaces et Hygiène des Matériaux, F-59651 Villeneuve d'Ascq, \\ France \\ d- STLO, Agrocampus Ouest, INRA, 35000 Rennes, France \\ e-UMET, UMR CNRS 8207, F-59655 Villeneuve d'Ascq, France
}

Corresponding author: Guillaume Delaplace

Inra CERTIA, Bâtiment PIHM, Unité Matériaux et Transformations

Institut National de la Recherche Agronomique, 369 rue Jules Guesde, BP 20039, 59651, Villeneuve d'Ascq, France

guillaume.delaplace@inra.fr

Highlights

- Solubility and fragmentation time are shown to be strongly correlated with rehydration times

- Ageing itineraries of MC powder can be defined from accelerated ageing tests

- Knowledge of ageing itinerary allow to predict the rehydration time of aged sample

\begin{abstract}
Controlled ageing conditions have been applied to two micellar casein (MC) powders and the consequent impact on their rehydration capacity and colorimetric evolution has been reported. Two characteristic times (fragmentation and total rehydration time) and solubility have been determinated to evaluate the evolution of rehydration capacity with controlled ageing conditions.
\end{abstract}


For the two MC powders tested, it was shown that the two characteristic times and the browning index increased with storage duration and temperature applied during ageing, whereas solubility decreased. For each MC powder studied, it was shown that i)there is a correlation (ageing curves) between the rehydration time (the target variable) and the indicator parameters (fragmentation time, browning index and solubility) and (ii)the shape of each ageing curve is independent of the ageing conditions but dependent on the MC powder studied.

These results clearly suggest the i)possibility to obtain reference ageing curves for each indicator, linking total rehydration time and the following indicators: fragmentation time, browning index and solubility ii)possibility to identify several ageing similarities between severe and moderate storage conditions iii)feasibility of applying accelerated ageing conditions to rapidly establish the shape of the reference ageing curves for a given MC powder, and iv)possibility of predicting the rehydration time of the MC powder studied using reference ageing curves through the measurement of one indicator (fragmentation time, browning index and solubility). This predicting ability of the proposed approach has been ascertained by comparing experimental and predicted values of rehydration time for aged samples having undergone storage accidents.

\section{Abbreviations}

MPC: milk protein concentrate; MC: micellar casein; P1: powder 1; P2: powder 2

Keywords: Casein micellar; powder; storage; rehydration 


\section{Introduction}

Milk protein concentrate (MPC) powders are produced from skimmed milk by spray drying after ultrafiltration (Haque et al., 2010). These dairy-derived powders have a high protein content, with the dry matter content ranging from 40 to $90 \%$ (De Castro-Morel \& Harper, 2002). The casein to whey protein ratio of MPC is identical to that of skimmed milk.

Due to their high nutritional value and favourable functional properties (e.g. foaming, emulsifying, gelling, etc.), MPC powders are incorporated as an ingredient into a wide range of applications in downstream food industries (Selomulya \& Fang, 2013). For example, they can be used to standardise the protein content of milk and are used as ingredients in many food applications including raising the protein content of cheese and yoghurt.

For most applications, a prior dissolution of MPC powder in water is mandatory in order to allow the powder to fully express its functional properties (Gaiani, Scher, et al., 2007) Consequently, rehydration and solubility are important end-use properties for MPC powders and require accurate assessment.

Unfortunately, several studies have reported that MPC powders are characterised by poor rehydration properties (Gaiani, Schuck, Scher, Desobry, \& Banon, 2007; Richard et al., 2013; Richard et al., 2012; P. Schuck et al., 2007). This is even truer for micellar casein (MC) powder, whether freshly prepared or stored. MC powder is a high-protein dairy powder obtained from milk microfiltration retentate. The objective is to eliminate almost all of the whey proteins, lactose and minerals (Schuck et al., 1994) and to concentrate the casein micelles while preserving their native structure. Due to the enriched micellar casein content, MC powder is an attractive material for the food industry, as it can enhance the structure, texture and consistency of various foodstuffs (Paracha, 2011; Singh, 2002). For powder enriched in micellar casein, it was i) shown that the total rehydration process required more than 3 hours at $25{ }^{\circ} \mathrm{C}$ under stirring at $900 \mathrm{rpm}$, and ii) observed that despite the 
aforementioned treatment, some undissolved material remained, which is generally referred to as the 'insoluble fraction' (Richard et al., 2013).

The impact of storage on the properties of MPC has been extensively studied (Anema, Pinder, Hunter, \& Hemar, 2006; Fang, Selomulya, Ainsworth, Palmer, \& Chen, 2011; Gazi \& Huppertz, 2015; Haque, Bhandari, Gidley, Deeth, \& Whittaker, 2015; Haque et al., 2012; Havea, 2006; Hunter, Hemar, Pinder, \& Anema, 2011; Jimenezflores \& Kosikowski, 1986; Le, Bhandari, \& Deeth, 2011; Marella, Salunke, Biswas, Kommineni, \& Metzger, 2015; Mimouni, Deeth, Whittaker, Gidley, \& Bhandari, 2010a, 2010b; Sikand, Tong, Walker, Wang, \& Rodriguez-Saona, 2016; Udabage, Puvanenthiran, Yoo, Versteeg, \& Augustin, 2012), with particular focus on the gradual loss of solubility during storage (Anema et al., 2006; Fyfe et al., 2011; Haque et al., 2012; Mimouni et al., 2010b). These studies have shown that the solubility and rehydration properties of MPC were negatively impacted by severe ageing conditions (temperature, humidity and storage time). Poor reconstitution properties, and hence poor functionality of high-micellar casein powders can prevent them from achieving full market potential (De Castro-Morel \& Harper, 2002). Thus, various studies have investigated ways of preventing insolubility of a powder, either by attempting to adjust adequate process parameters during filtration and spray drying operations (namely the drying inlet temperature conditions for example (Schuck et al., 1994), or by adapting the initial retentate formulation. It was found that adding monovalent salts to the ultrafiltered retentate prior to drying may improve solubility while increasing the calcium/total mineral ratio decreases the solubility of MPC (Carr, Bhaskar, \& Ram, 2002).

At present, protein destabilisation due to conformational changes (Fyfe et al., 2011; Haque et al., 2010; Haque, Bhandari, Gidley, Deeth, \& Whittaker, 2011; Haque et al., 2015; Haque et al., 2012; Kher, Udabage, McKinnon, McNaughton, \& Augustin, 2007) and Maillard reactions in the presence of lactose (Haque et al., 2010; Haque et al., 2011, 2015; Le, Processing, 106, 181-192. , DOI : 10.1016/j.fbp.2017.09.004 
Bhandari, \& Deeth, 2011; Le, Bhandari, Holland, \& Deeth, 2011; Le, Holland, Bhandari, Alewood, \& Deeth, 2013) are the most frequently cited causes for the loss of rehydration properties at molecular level.

Development of insolubility of the two high-micelle-casein-content powders, MC and MPC, is believed to share similar mechanisms, nevertheless MC has been less studied and the exact relationship between storage and changes in rehydration properties is not yet precisely known. From analysis of state of the art, it also appears that the colorimetric change in MC powder with ageing (browning index) has been poorly documented.

Further work is thus needed to establish the influence of storage temperature and time on the ageing of MC powders and to illustrate the link between rehydration time and other ageing indicators (solubility, fragmentation time and browning index). Providing experimental data addressing this issue is the main aim of this study rather than to investigate $\mathrm{MC}$ at molecular scale or to establish a relationship between structural modifications and changes in rehydration/browning properties. At present, protein instability in its dry form (conformational modifications and water-protein interaction) and Maillard reaction due to the non limiting lactose content are the most frequently cited causes to explain the loss of MPC rehydration properties (Haque et al., 2010; Haque et al., 2011, 2015). However and more specifically, (Nasser et al., 2017) recently showed that the lipid migration towards the particle surface and the surface densification of micellar particles were responsible for major changes in MC rehydration dynamics during storage.

In order to provide such temperature-time correspondences upon ageing, MC was stored at temperatures ranging from 4 to $60^{\circ} \mathrm{C}$ for periods up to 12 months. The evolution of various indicators (evolution of browning index, change in solubility, fragmentation time and total rehydration time) upon ageing was evaluated. The first part of this article consists in analyzing the indicators' evolution with time and to assess for any MC the temperature-time Processing, 106, 181-192. , DOI : 10.1016/j.fbp.2017.09.004 
correspondences upon ageing. The second part of this paper is devoted to ascertaining whether or not relevant master curves exist between these indicators. If established, these curves will help identify indicators which could be used to rapidly quantify and predict MPC powder's loss of rehydration capacity with ageing.

\section{Materials and methods}

2.1. Dairy powders manufacture: physicochemical analysis at inlet and outlet of the spray drying tower and process parameters

MC concentrates were obtained through microfiltration (pore size $=0.1 \mu \mathrm{m}$ ) of skimmed milk from Ingredia (Arras, France).

Powders were obtained by spray drying an MC concentrate in a pilot workshop (GEA, Niro Atomizer, St Quentin en Yvelines, France) at Bionov (Rennes, France). The same operating conditions as described by Pierre, Fauquant, Legraet, Piot, \& Maubois (1992) and Schuck et al. (1994) were used for the spray drying. The inlet temperature was $180{ }^{\circ} \mathrm{C} \pm 10^{\circ} \mathrm{C}$ and the outlet temperature was $65 \pm 5^{\circ} \mathrm{C}$.

Two batches of MC powder were prepared (P1 and P2). Various physico-chemical analyses were performed on the initial microfiltration retentates and the resulting dairy powders. The nitrogen contents (total nitrogen, non-casein nitrogen, non-protein nitrogen) of initial statefresh powder were determined as described by Schuck et al., (2012). The total nitrogen content, non-casein nitrogen content corresponding to the soluble fraction at $\mathrm{pH} 4.6$, and nonprotein nitrogen content corresponding to the insoluble fraction after their precipitation were determined by the Kjeldhal method. Nitrogen contents were converted into protein contents using 6.38 as multiplying factor. These analyses are reported in Table $\mathbf{1 .}$ 
MC powders were packed into individual $380 \mathrm{~g}$ tin cans after manufacture. The powders were stored at controlled temperatures of $4{ }^{\circ} \mathrm{C}$ (referred to as "reference powder"), $20{ }^{\circ} \mathrm{C}, 40{ }^{\circ} \mathrm{C}$ and $60{ }^{\circ} \mathrm{C}$ for various durations to a maximum of 12 months.

\subsection{Determination of solubility}

To determine solubility, aqueous solutions of $5 \%(\mathrm{w} / \mathrm{w}) \mathrm{MC}$ powder were firstly prepared in distilled water at room temperature for 1 hour under stirring. Then, $50 \mathrm{ml}$ of the $\mathrm{MC}$ solution was transferred into $50 \mathrm{ml}$ centrifugation tubes and centrifuged using a Sigma 6K15 refrigerated centrifuge (Sigma, Labozentrifugen GmbH, Osterode am Harz, Germany) at 700 $\times \mathrm{g}$ at $20^{\circ} \mathrm{C}$ for $20 \mathrm{~min}$. The supernatant was placed in a preweighed moisture dish and weighed. After that, the moisture dish (filled with the supernatant) was dried for $24 \mathrm{~h}$ in an oven at $105^{\circ} \mathrm{C}$ before being cooled down to room temperature in a desiccator containing dry silica gel to avoid condensation and then reweighed. The percentage of soluble material $(\sigma)$ of the MC powder was calculated using the following equation (Anema et al., 2006):

$\sigma=\frac{\text { Weight of dry material }}{\text { weight of solution }} \times 100 \quad$ Eq. (1)

It represents the solids in the ultracentrifugal supernatant, expressed as a percentage of total soluble solids in the whole solution. The $\sigma$ values of aged powder samples were compared to that of the reference powder, and this $\sigma($ aged $) / \sigma($ reference) ratio in percentage was used to study the solubility evolution during ageing.

\subsection{Colour measurement of MC powder and browning index determination}

The colour measurements were carried out during storage. A CR-300 Minolta colorimeter (Konica Minolta, Osaka, Japan) run in the L-a-b space was used. Prior to measurements, values of $L^{*}, a^{*}$ and $b^{*}$ were calibrated with a standard reference: 96.03, 4.71 and 7.24, respectively. After dispersion of powder on a Petri dish, colour measurement was carried out 
on 3 different points on the surface of the receptacle. The browning index (BI), used to assess the intensity of the brown colour of the samples, was calculated from formula combining the L*a*b* (Oliveira, Sousa-Gallagher, Mahajan, \& Teixeira, 2012):

$$
\mathrm{BI}=\frac{[100(\mathrm{x}-0,31)]}{0,17} \quad \mathrm{Eq} .(2)
$$

With $\mathrm{x}=\frac{\left(\mathrm{a}^{*}+1.750 \times \mathrm{L}^{*}\right)}{\left(5.645 \times \mathrm{L}^{*}+\mathrm{a}^{*}-3.012 \times \mathrm{b}^{*}\right)} \quad$ Eq. (3)

\subsection{Rehydration tests}

The equipment used for performing rehydration tests has been previously described by Richard et al. (2013; 2012).

MC powders were reconstituted at $8 \%(\mathrm{w} / \mathrm{w})$ dry matter content. This concentration is commonly used in dairy applications at industrial scale. The dairy powder was added manually to the free liquid surface. The powder rehydration protocol was described in a previous publication (Jeantet, Schuck, Six, Andre, \& Delaplace, 2010). The rehydration protocol and sampling site were kept constant throughout all the experiments.

After the addition of powder to the liquid surface (at a stirring rate of $900 \mathrm{rpm}$ ), the impeller rotational speed of the agitator $\mathrm{N}$ was set at 1,200 rpm for 45 seconds to ensure that the powder was fully incorporated into the liquid. Then, $\mathrm{N}$ was set at a constant speed of $900 \mathrm{rpm}$ until the end of the rehydration test. It should be noted that a turbulent flow regime and full suspension of powder particles were achieved at this $\mathrm{N}$ value.

2.5. Granulomorphometer measurements and determination of fragmentation time 
Digital images of powder particles during the course of the rehydration tests were obtained using the Flow-Cell272 200 S-M (Occhio, Angleur, Belgium) granulomorphometer. This microscopy technique makes it possible to analyse samples, diluted or not, of the MC suspension pumped into the vessel of the rehydration test. The principle of this granulomorphometer was described in a previous publication (Richard et al., 2012). Readers can refer to this article for more details.

As previously described by Richard et al. (2012), the fragmentation time has been defined as the time required to reach the maximum number of particles during the rehydration test.

\subsection{Static light scattering and determination of total rehydration time}

As described by Richard et al. (2012), particle size distribution, measured by SLS (Static Light Scattering, Mastersizer 2000, Malvern Instruments Ltd, England) was used to determine the total rehydration time for each test. Sampling was done as follows: $0.5 \mathrm{~mL}$ of the powder suspension was withdrawn with a 16-mm-diameter syringe from the rehydration vessel. Samples were diluted in the Malvern cell (volume: $100 \mathrm{~mL}$ ) with distilled water to reach appropriate obscuration $(25 \%)$. The solvent and particle refractive indices were set at 1.33 and 1.3, respectively, for particle size distribution measurements. The absorption index was set at 0.1 . The class size limits were $0.02-2,000 \mu \mathrm{m}$. Particle size distribution was measured every 5 minutes until the fragmentation time was complete, and then approximately every 30 minutes as long as the size of the particles was larger than $15 \mu \mathrm{m}$ and finally every 5 minutes until the end of the experiment when reaching the total rehydration time. According to Richard et al. (2012), the total rehydration time was defined as the time required for Dv50, medium value of the particle size distributions, to reach $0.2 \mu \mathrm{m}$ after the addition of powder. The mean standard deviation of total rehydration time results was equal to $11.4 \%$. Similar values of standard deviation for different powders were obtained by Jeantet et al.,(2010). 


\subsection{Statistical analysis}

Student's $t$-tests with a 0.05 level of significance were used to measure the significance of the differences between samples stored and reference powder none stored. As widely known, the differences are statistically nonsignificant when $\mathrm{p}>0.05$ and statistically significant when $\mathrm{p}<$ 0.05

\section{Results \& discussion}

Firstly, experimental data collected for MC P1 for the 4 different storage temperatures are presented and discussed.

\subsection{Browning index evolution with ageing conditions}

The change of colour visually observed for the MC P1 as a function of storage time for different storage temperatures is illustrated in Figure 1A. As expected, it clearly appears that browning is strongly influenced by the storage temperature set. Browning occurred faster when the storage temperature increased. At a storage temperature of $60{ }^{\circ} \mathrm{C}$, the increase of the brown coloration of the powder is so significant that it is clearly detectable even by naked eyes.

The evolution of the BI for MC P1 stored at different temperatures as a function of time is illustrated in Figure 1B. The BI of the MC P1 stored at $4{ }^{\circ} \mathrm{C}$ and $20^{\circ} \mathrm{C}$ evolves slightly from 8.34 to 8.43 and 8.72 , respectively, after 365 days of storage $(p<0.05)$. However, the BI indicator of the MC P1 stored at $40{ }^{\circ} \mathrm{C}$ showed a significant slight linear evolution $(\mathrm{p}<0.05)$ over the whole range of storage time studied (360 days). At $60{ }^{\circ} \mathrm{C}$, the evolution of BI with storage time for MC P1 was so drastic that an increase of $50 \%$ was achieved after only 5 days of storage. In fact, the change in BI over time at $60{ }^{\circ} \mathrm{C}$ is characterised by a two-step mechanism: During the first 60 days of storage, BI increased linearly with storage time (with 
a slope equal to 0.46$)(\mathrm{p}<0.05)$. Then for the storage period from 60 to 360 days, the increasing rate of BI decreased down to nearly 0 and a plateau was observed $(\mathrm{p}>0.05)$. In the literature, it is often suggested that the presence of small quantities of lactose is sufficient to trigger a Maillard reaction. Indeed, interactions between lactose and lysine can occur, leading to food properties evolution like colour, flavour and nutritional value (Martins, Jongen, \& van Boekel, 2000).

Typically, both the temperature and the storage time have been proven to impact the Maillard reaction. For the MC P1 investigated, it is highly probable that such phenomena were also involved in the browning process.

\subsection{Solubility evolution with ageing conditions}

The solubility of MC P1 stored at different temperatures is plotted as a function of time in Figure 2. Like what was observed for BI, evolution of solubility with storage time also reveals to be highly dependent on the storage temperature.

The MC P1 stored at $20{ }^{\circ} \mathrm{C}$ showed little change in solubility over a storage time of 180 days. It could be observed that the solubility slightly and linearly decreased from $100 \%$ to $\sim 80 \%$ over that period of storage.

A different solubility evolution upon ageing is observed when storage temperature increases. Indeed, the solubility of MC P1 stored at $40{ }^{\circ} \mathrm{C}$ drastically decreased in the first days of ageing, then after 60 days of storage at this temperature a plateau was reached and the solubility became constant at around $25 \%$ of the initial value. This drastic decrease of solubility at the first instant of storage at a higher storage temperature was amplified when ageing occurred at $60^{\circ} \mathrm{C}$. It could be noticed that the solubility of the $\mathrm{MC}$ P1 stored at $60^{\circ} \mathrm{C}$ decreased dramatically after $8 \mathrm{~h}$ of storage and reached an asymptotic value of $\sim 15 \%$ at 60 
days of storage. For these two most severe storage conditions tested, the solubility was first subjected to an exponential decay then reached an asymptotic value.

The loss of solubility observed for MC P1 at higher storage temperatures was in agreement with both the expected trend (increase in quantity of insoluble material with time and storage temperature) and previous studies of high-protein dairy powder (Anema et al., 2006; Gazi \& Huppertz, 2015; Le, Bhandari, \& Deeth, 2011; Le, Bhandari, Holland, et al., 2011)

From further analysis of the experimental data, it appeared that solubility and browning index didn't follow the same evolution with storage time: decay with time is observed for solubility whereas a growth is noticed for BI. For a given storage temperature, the monotonicity and rates of change of these two indicators vary differently with storage time. Indeed, for a storage temperature fixed at $40{ }^{\circ} \mathrm{C}$, the change in solubility followed an exponential decrease contrary to the change in BI, which followed a linear growth at this temperature (Figure 1). Similarly, the BI values did not change with time during storage at $20{ }^{\circ} \mathrm{C}$, whereas solubility decreased by $23 \%$. This kinetic difference clearly indicates that loss of solubility and increase in browning during storage are not induced by the same phenomena and consequently the evolution of these two indicators are unlikely to be governed by the apparition of the same chemical species at molecular level.

\subsection{Fragmentation time evolution with ageing conditions}

Figure 3 shows the change in fragmentation time of MC P1 stored at various temperatures for varying storage times. It can be observed that the storage temperature modify strongly the shape of the fragmentation time / storage time curve. Indeed, the fragmentation time of MC P1 stored at $4{ }^{\circ} \mathrm{C}$ doesn't evolve with storage time (p>0.05), and barely evolves at $20{ }^{\circ} \mathrm{C}$ $(\mathrm{p}<0.05)$. In contrast, the fragmentation time of MC P1 stored at $40{ }^{\circ} \mathrm{C}$ exhibited a 10 -fold increase after 15 days of storage and increase significantly until 2 months of storage. The 
change in the fragmentation time of $\mathrm{MC} \mathrm{P} 1$ stored at $60{ }^{\circ} \mathrm{C}$ was even more drastic over time, with a 15 -fold increase after only 2 days of storage and increase significantly until 5 days of storage.

To our knowledge, there is yet no study reported on fragmentation time evolution upon ageing. We are the first group to report this indicator evolution with storage time for various storage temperatures. Consequently, it is difficult to do further discussion and comparison on the experimental data obtained. Nevertheless, the change in fragmentation time should be regarded as an indicator which quantifies the ease of dissolution of the solid bridges between cross-linked micellar caseins. Consequently, the increase of fragmentation time with the severity of ageing that we observed is actually in agreement with the work of Anema et al., (2006), who have reported a cross-linking increase with storage time and temperature. Indeed, the increase of protein cross-linking during storage makes it more difficult to fragment and dissolve the particles.

\subsection{Rehydration time evolution with ageing conditions}

The rehydration time of MC P1 is plotted against storage time in Figure 4. Again, temperature was observed to have a major impact on the evolution of total rehydration time upon ageing. The total rehydration time, after 12 months of storage, increased from $\sim 3.5 \mathrm{~h}$ to $\sim 5 \mathrm{~h}$ for the powder stored at $4{ }^{\circ} \mathrm{C}(\mathrm{p}<0.05)$ and from $\sim 3.5 \mathrm{~h}$ to $\sim 7 \mathrm{~h}(\mathrm{p}<0.05)$ for the powder stored at $20{ }^{\circ} \mathrm{C}$. It is worth re-mentioning that a $23 \%$ decrease in solubility was observed after 6 months of storage for the powder stored at $20^{\circ} \mathrm{C}$ (Figure 2).

These changes in total rehydration time over storage period are relatively mild when compared to storage at $40{ }^{\circ} \mathrm{C}$ and $60{ }^{\circ} \mathrm{C}$. Indeed, the rehydration time doubled for MC P1 stored at $40{ }^{\circ} \mathrm{C}$ after 15 days $(\mathrm{p}<0.05)$ and reached $\sim 29 \mathrm{~h}$ after 2 months of storage $(\mathrm{p}<0.05)$. 
The change in rehydration time of MC P1 stored at $60{ }^{\circ} \mathrm{C}$ was even more drastic. Its value has more than doubled after only $24 \mathrm{~h}$ of storage $(\mathrm{p}<0.05)$ and reached $\sim 35 \mathrm{~h}$ after only 5 days of storage $(\mathrm{p}<0.05)$. These results indicate that basically insolubility developed under all storage conditions, but at different rates depending on the storage temperature.

It seemed that the storage-temperature dependent rehydration time and solubility changes are intimately linked; the lower the solubility, the longer the rehydration time. This is in agreement with several works that have previously referred to this trend for MPC powder (Anema et al., 2006; Gazi \& Huppertz, 2015).

As suggested by Fyfe et al., (2011) and Mimouni et al., (2011; 2010a) insolubility can be caused by the formation of a network of cross-linked proteins at the surface of the powder. These surface cross-links act as a barrier to the transport of water which inhibits the hydration of the particles, their subsequent disruption and dissolution, leading to the increase of both fragmentation time and total rehydration time. The increase in the degree of cross-linking with increasing storage time and temperature reported by Anema et al., (2006) is consistent with this interpretation.

The greater the severity of storage conditions, the more the indicators change. However, it is still difficult at this stage to assess whether indicator parameters (fragmentation time, solubility loss and browning index) could be used to rapidly predict the increase in rehydration times due to ageing. The objective of the next section is to address this issue.

3.5. Correlation between indicators (fragmentation times, solubility and Browning Index) and rehydration time for $\mathrm{MC}$ P1

Firstly, rehydration time versus solubility (Figure 5A) and rehydration time versus fragmentation time were plotted (Figure 5B). These two indicators (fragmentation times and 
solubility) were analysed first rather than browning index since the underlying phenomena involved in the evolution of these two indicators are expected to be the same as those governing the rehydration time evolution during ageing. As evoked previously, it is not so evident that the BI change is closely connected to rehydration properties evolution. Indeed, browning and insoluble formation are not necessarily induced by the same chemical modification pathway. Analysis of Figures 5A and 5B reveals that each pair of indicators ([solubility; rehydration time] and [fragmentation time; rehydration time] respectively) follows a reference ageing curve, which could be described using a linear function independent of the storage time and temperature set during ageing. The fitting functions are given by Equation $4(\mathrm{~A} \& \mathrm{~B})$ for Figure $5 \mathrm{~A}$ and by Equation 5(A\&B) for Figure 5B.

Rehydration time $=-0.08 \times$ solubility +12.13 with $\mathrm{R}^{2}=0.96$ if solubility $>33 \%$ Eq. (4A)

Rehydration time $=-2.83 \times$ solubility +101.58 with $\mathrm{R}^{2}=0.86$ if solubility $<33 \%$ Eq. (4B)

Rehydration time $=2.06 \times$ fragmentation time +4.13 with $\mathrm{R}^{2}=0.81$ if fragmentation time $<4.80$ Eq. $(5 \mathrm{~A})$

Rehydration time $=15.20 \times$ fragmentation time -60.09 with $\mathrm{R}^{2}=0.61$ if fragmentation time $>4.80$ Eq. (5B)

In a second time, the rehydration time versus browning index was plotted (Figure 5C).

Similarly, the analysis of this figure also reveals the existence of an ageing curve independent of the storage time and temperature for this indicator (Equation 6).

Rehydration time $=0.0004 \times$ Browning Index ${ }^{4.4}$ with $\mathrm{R}^{2}=0.90$ Eq. (6) 
The existence of these reference ageing curves and fitting functions (Equations 4-5-6) are of interest. The time-consuming and tedious-experimental-protocol requiring rehydration time determination process could be simplified since the rehydration time could be rapidly predicted through the determination of fragmentation time or solubility. This is to say that it would be sufficient to carry out fragmentation time or solubility measurements, which are among the easiest tests, to rapidly estimate the rehydration time for the solid-liquid suspension. Based on this method, process parameters (for example rotational impeller speed, $\mathrm{N}$ for rehydration in agitated vessel equipped with vertical agitator centrally mounted) can be easily adjusted to achieve the desired product quality and functionality (Jeantet et al., 2010; Richard et al., 2013).

The discovery that reference ageing curves exist and gather all the aged samples of the MC P1 studied is of interest. Indeed, this fact suggests that changes occurred at the highest temperatures over a short storage period could mimic changes occurred under milder temperature conditions over a longer period of time. Therefore, it can be envisaged to establish, under accelerated ageing conditions, the ageing curves for MC P1 which are also valid for less severe conditions. For example, the approximate rehydration time / solubility ageing curve of MC P1 can be plotted using 3 experimental points: initial state and after 2 and 5 days of storage at $60^{\circ} \mathrm{C}$. Ces 3 points ont été choisi car couvre l'ensemble des données experimental. Evidemment,plus le nombre de points à vieillissement accéléré est important, plus la precision de la courbe approximé sera importante.

Linear regression of the 2 straight lines obtained by connecting the three experimental points leads to the following equations (Equations 7-8-9) :

\footnotetext{
Rehydration time $=-0.11 \times$ solubility +14.84 with $\mathrm{R}^{2}=1$ if solubility $>29.21 \%$ Eq. (7A)

Rehydration time $=-4.50 \times$ solubility +142.74 with $\mathrm{R}^{2}=1$ if solubility $<29.21 \%$ Eq. (7B)
} 
Rehydration time $=3.44 \times$ fragmentation time +2.86 with $\mathrm{R}^{2}=1$ if fragmentation time $<2.52$ Eq. $(8 \mathrm{~A})$

Rehydration time $=6.16 \times$ fragmentation time -3.99 with $\mathrm{R}^{2}=1$ if fragmentation time $>2.52$ Eq. (8B)

Rehydration time $=3.17 \times$ Browning Index -21.90 with $\mathrm{R}^{2}=0.93$ if IB $<10.8$ Eq. (9A)

Rehydration time $=7.40 \times$ Browning Index -68.43 with $R^{2}=1$ if IB $>10.8$ Eq. (9B)

It could be noticed on figure 5 that "the approximated ageing curves", established using only 3 accelerated ageing points (dotted line) are not far away from the reference ageing curves (obtained with all the data points tested, in solid line). In this demonstration, only 3 points were used to obtain the approximated ageing curve, because they are sufficient to cover all the experimental data. Obviously, the greater the number of accelerated ageing points used, the more accurate the approximated ageing curve will be.

3.5. Confirmation of the existence of reference ageing curves and possibility to establish ageing curves using accelerated ageing conditions for MC P2

To confirm the existence of reference ageing curves independent of temperature and storage time for each indicator (solubility, fragmentation time, browning index), as obtained for MC P1, experimental study with another MC powder derived from a different retentate, named MC P2, was performed.

The functional properties (browning index, solubility, fragmentation and total rehydration times) of the two MC powders (reference powder stored at $4{ }^{\circ} \mathrm{C}$ and aged powder stored for 5 days at $60{ }^{\circ} \mathrm{C}$ ) are reported in Table 2. It was observed that the final browning index of the 
aged MC P2 powder is lower than that of the aged MC P1 powder. Moreover, it turned out that rehydration properties of the two aged powders are markedly different after 5 days of storage at $60{ }^{\circ} \mathrm{C}$ : a total rehydration is achieved more quickly for powder 2 compared to powder 1 .

Firstly, since lactose is responsible for the brown colour of the powders (via the Maillard reaction), the lower lactose content of MC P2 explains its lower browning index.

Secondly, the dry matter compositions of the two retentates are comparable. The lower dry extract of MC P2 implies hence a lower viscosity of retentate 2 (Devilder \& Moermans, 1983; P. Schuck, Mejean, Dolivet, Beaucher, \& Famelart, 2005; Snoeren, Dammam, \& Klok, 1982) explaining the smaller particle size of the powder produced by spray drying (Baldwin, Baucke, \& Sanderson, 1980; Masters, 2002), as shown in Table 1. When the viscosity of the feed liquid increases, more energy is dissipated in the spray tower nozzle to overcome viscous forces. Thus the energy available for breaking up the droplets is reduced, resulting in larger droplets. Therefore, smaller droplets are formed for a less viscous liquid.

Finally, it is widely recognised since the pioneer work of Noyes-Whitney, (1897) that the dissolution rate of chemical particles is faster for smaller ones because the specific surface area increases when particle size decreases. The review of Dokoumetzidis \& Macheras, (2006) and the work of Gaiani et al. (2007) have also confirmed this physical law respectively for biopowders and for milk derivative powders. It is evidenced that the dispersion step (corresponding to the dispersion of single particles throughout the water) is favoured when particle size decreases. As dispersion is known to be the limiting step of MC powder rehydration (Gaiani, Schuck, et al., 2007), it is logical to consider the smaller particle size of MC P2, resulting from viscosity difference in the drying operation, to be responsible for its faster rehydration. 
The relationships between the different indicators and the rehydration times were plotted for MC P2. The reference ageing curves obtained for this second batch MC P2 are presented in

Figure 6. The corresponding fitting functions are as follows (Equations 10 to 12):

Rehydration time $=8834.2 \times$ solubility $^{-2.2}$ with $\mathrm{R}^{2}=0.98$ Eq. (10)

Rehydration time $=-0.1 \times$ fragmentation time ${ }^{2}+2.2 \times$ fragmentation time +0.3 with $\mathrm{R}^{2}=$ 0.94 Eq. (11)

Rehydration time $=0.5 \times$ Browning Index $^{2}+11.1 \times$ Browning Index -55 with $\mathrm{R}^{2}=0.94 \mathrm{Eq}$.

Unsurprisingly, the shape of reference ageing curves and type of mathematical equations for MC P2 were very different from MC P1. But this new set of results confirmed again anyway the possibility of obtaining reference ageing curves that link the rehydration time with each individual indicator (fragmentation time, browning index and solubility), regardless of the ageing conditions adopted during storage. Experimental data obtained for MC P2 also corroborate the idea that applying accelerated ageing conditions is an interesting way to predict the changes that would occur under milder conditions (lower temperatures). As for previous MC P1 investigated, three conditions of storage seem particularly interesting to examine the predictive trajectory of ageing curves: initial state and after 2 and 5 days' storage at $60^{\circ} \mathrm{C}$.

The equations for the ageing curves of MC P2 established on these three ageing points using a linear regression per interval are as follows:

Rehydration time $=-0.09 \times$ solubility +9.67 with $\mathrm{R}^{2}=1$ if solubility $>27 \%$ Eq. 
Rehydration time $=-0.63 \times$ solubility +24.05 with $\mathrm{R}^{2}=1$ if solubility $<27 \%$ Eq. (12B)

Rehydration time $=3.71 \times$ fragmentaion time +0.16 with $\mathrm{R}^{2}=1$ if fragmentation time $<1.87$ Eq. $(13 \mathrm{~A})$

Rehydration time $=0.61 \times$ fragmentation time +5.98 with $\mathrm{R}^{2}=1$ if fragmentation time $>1.87$ Eq. $(13 B)$

Rehydration time $=5.14 \times$ browning index -34.78 with $\mathrm{R}^{2}=1$ if browning index $<$ 8.15 Eq. (14A)

Rehydration time $=1.85 \times$ browning index -7.96 with $\mathrm{R}^{2}=1$ if browning index $>8.15$ Eq. (14B)

Again, it could be remarked on figure 6 that the ageing curves established using these 3 accelerated ageing conditions (dotted line) give good approximation of reference ageing curves obtained using all experimental data points (solid line).

Further observations of the reference ageing curves (Figures $5 \& 6$ ) made it possible to identify and confirm several ageing similarities between severe and moderate ageing conditions. For example, ageing after a period of 8 hours at $60{ }^{\circ} \mathrm{C}$ was approximately equivalent to ageing after a period of 12 months at $20^{\circ} \mathrm{C}$, the condition commonly encountered during powder storage and delivery. In the same way, ageing after a 24 hour period at $60{ }^{\circ} \mathrm{C}$ is equivalent to that after 1 month period at $40{ }^{\circ} \mathrm{C}$. These equivalences are outlined in blue bold in Figure $5 \& 6$. These [storage time; storage temperature] concordances are of great help to rapidly predict property changes of the powder during storage. 
In previous section, it has been suggested to rapidly identify the shapes of reference ageing curves for the MC powder studied (by using accelerated ageing conditions). It is then necessary to assess the accuracy of predicted rehydration times. The objective of the next section 3.6. is to address this issue. A reverse engineering approach is proposed based on the approximate ageing curves obtained and the measurements of indicators.

3.6 Comparison between experimental and predicted rehydration time

In order to assess the feasibility of predicting the rehydration time for aged samples, experimental and predicted values have been compared for the two MC powders studied. The 4-step procedure used to determine the predicted rehydration time is as follows:

Step 1. Indicator (solubility, fragmentation time or BI) and rehydration time values of the powder studied are measured for three particular ageing conditions (initial state-fresh powder and two accelerated ageing conditions -2 and 5 days of storage at $60{ }^{\circ} \mathrm{C}$ )

Step 2. The three experimental points obtained [indicator; rehydration time] are plotted to obtain a first approximated ageing curve

Step 3. The equations of the approximate ageing curve are obtained through linear regression of the 2 straight lines connecting the 3 points.

Step 4. The indicator is measured for an arbitrary aged sample and the corresponding rehydration time value is evaluated using the set of equations obtained at step 3 by inverse engineering approach

Comparisons between experimental and predicted values of rehydration time for MC powders $\mathrm{P} 1$ and $\mathrm{P} 2$ are presented in Figure 7. Namely, Figures 7A, 7B and 7C give the comparisons based respectively on different indicators (solubility, fragmentation and browning index). 
Predicted values were obtained using approximated ageing curves previously established (Figures 5A-5B-5C for MC P1 and Figures 6A-6B-6C for MC P2).

Dark circle symbols in Figure 7A, 7B and 7C represent results for MC P1 while grey square symbols represent results for MC P2. Additional experiments under controlled storage conditions were carried out to ascertain the validity and accuracy of the proposed procedure for the prediction of rehydration time. These experimental points are presented in Figure 7A, 7B and 7C as cross symbols and will be commented more in details further in the text

Whatever the indicator used, it could be observed in Figures 7A to 7C that there is a good agreement between predicted and experimental values of rehydration times. Indeed all the data are located in the proximity of the bisector line and the maximum percentage of error is inferior to $25 \%$. The predicted values are rather good since the standard deviation for experimental determination of rehydration time is relatively high (around 11.4\%). Of course, if more numerous accelerated ageing conditions are applied and used to plot the approximate ageing curves, a more exact approximation can be achieved with appreciably reduced deviations between predicted and experimental values. In this case, the equations of the approximate ageing curves will become similar to that describing the reference ageing curves (Equations 7-9 and 10-12, depending on the MC powder studied and the indicators considered). In this context, it is obvious that a compromise between the accuracy of predicted values and experimental time consumed to build ageing curves should be chosen. Nevertheless, from a practical aspect, the feasibility to apply the proposed procedure for fast prediction of rehydration time has been demonstrated for the two powders studied.

To go further, it was decided to check the procedure with an independent series of data. 6 additional samples of aged powder were studied for this purpose. The independent series of data was obtained by subjecting MC P1 powder to storage accidents (short exposure to high 
temperatures close to $60{ }^{\circ} \mathrm{C}$ ). Note that this kind of storage accidents are episodes that a powder is proved to undergo during its ship expedition (Leinberger, 2006). Consequently, predicting the effect on powder properties of such short exposure to high temperature is of great interest for both industries and consumers.

6 different accidents of storage were imposed for the 6 aged samples and measurements of indicator parameters and rehydration times were carried out. The ageing conditions of these additional samples and the exact instantaneous time for storage accident are presented in detail Figure 8. Sample 1 has been stored for 5 months at $20^{\circ} \mathrm{C}$ with no storage accident. Samples 2, 5 and 6 have been stored for 5 months at $20^{\circ} \mathrm{C}$ including one storage accident (a rise in temperature to $60{ }^{\circ} \mathrm{C}$ and then maintained at $60{ }^{\circ} \mathrm{C}$ for $8 \mathrm{~h}$ after the temperature rise) at different storage times. Sample 5 and 6 have been stored for 5 months at $20{ }^{\circ} \mathrm{C}$ including respectively two and three storage accidents. (Figure S1).

Predicted rehydration time values of these additional samples subjected to storage accidents have been obtained using the procedure described above. Again, the experimental and predicted values of rehydration time for these additional samples are in good agreement. This further validates our rehydration time prediction procedure based on the determination of indicator parameters and corresponding ageing curves (which could be established by imposing accelerated ageing conditions).

\section{Conclusion}

To conclude, it has been shown that the characteristic rehydration times (total rehydration time and fragmentation time) as well as the browning index increased with storage time and temperature, whereas solubility decreased for both MC powders studied. 
Ageing curves were plotted for each indicator, linking total rehydration time with fragmentation time, browning index and solubility. Several ageing similarities between severe storage and moderate storage have been demonstrated. The shape of each ageing curve depends only on the MC powder, not on ageing conditions.

It has then been shown that applying accelerated ageing conditions made it possible to visualize the reference ageing curves of the MC powders to be characterised. 3 samples subjected to three particular ageing conditions (initial state-fresh powder and two accelerated ageing conditions - 2 and 5 days of storage at $60{ }^{\circ} \mathrm{C}$ ) were used for this purpose.

With the approximate ageing curves, the rehydration time can be rapidly predicted by measuring one indicator.

Finally, feasibility of obtaining predicted values of rehydration times was also demonstrated for a MC powder having undergone storage accidents (one or more temperature rises to $60^{\circ} \mathrm{C}$ in the course of 5 months of storage).

\section{Acknowledgements}

This work was carried out within the framework of a CNIEL research program and deal issues of the ALIBIOTECH research project. Consequently, the authors would like to acknowledge the CNIEL and also thank the Haut de France region and FEDER for their financial support. 


\section{References}

Anema, S. G., Pinder, D. N., Hunter, R. J., \& Hemar, Y. (2006). Effects of storage temperature on the solubility of milk protein concentrate (MPC85). Food Hydrocolloids, 20(2-3), 386-393. doi:10.1016/j.foodhyd.2005.03.015

Baldwin, A. J., Baucke, A. G., \& Sanderson, W. B. (1980). The effect of concentrate viscosity on the properties of spray-dried skim milk powder. New Zealand Journal of Dairy Science and Technology, 15(3), 289-297.

Carr, A., Bhaskar, G., \& Ram, S. (2002). Monovalent salt enhances solubility of milk protein concentrate. In: WO02/096208.

De Castro-Morel, M., \& Harper, W. J. (2002). Basic functionality of commercial milk protein concentrates. Milchwissenschaft-Milk Science International, 57(7), 367-370.

Devilder, J., \& Moermans, R. (1983). The continous measurement of the viscosity of the concentrate during the production of milk powder. Milchwissenschaft-Milk Science International, 38(8), 449-452.

Dokoumetzidis, A., \& Macheras, P. (2006). A century of dissolution research: From Noyes and Whitney to the Biopharmaceutics Classification System. International Journal of Pharmaceutics, 321(1-2), 1-11. doi:10.1016/j.ijpharm.2006.07.011

Fang, Y., Selomulya, C., Ainsworth, S., Palmer, M., \& Chen, X. D. (2011). On quantifying the dissolution behaviour of milk protein concentrate. Food Hydrocolloids, 25(3), 503-510. doi:10.1016/j.foodhyd.2010.07.030

Fyfe, K. N., Kravchuk, O., Le, T., Deeth, H. C., Nguyen, A. V., \& Bhandari, B. (2011). Storage induced changes to high protein powders: influence on surface properties and solubility. Journal of the Science of Food and Agriculture, 91(14), 2566-2575. doi:10.1002/jsfa.4461

Gaiani, C., Scher, J., Ehrhardt, J. J., Linder, M., Schuck, P., Desobry, S., \& Banon, S. (2007). Relationships between dairy powder surface composition and wetting properties during storage: Importance of residual lipids. Journal of Agricultural and Food Chemistry, 55(16), 6561-6567. doi:10.1021/jf070364b

Gaiani, C., Schuck, P., Scher, J., Desobry, S., \& Banon, S. (2007). Dairy powder rehydration: Influence of protein state, incorporation mode, and agglomeration. Journal of Dairy Science, 90(2), 570-581.

Gazi, I., \& Huppertz, T. (2015). Influence of protein content and storage conditions on the solubility of caseins and whey proteins in milk protein concentrates. International Dairy Journal, 46, 2230. doi:10.1016/j.idairyj.2014.09.009

Haque, E., Bhandari, B. R., Gidley, M. J., Deeth, H. C., Moller, S. M., \& Whittaker, A. K. (2010). Protein Conformational Modifications and Kinetics of Water-Protein Interactions in Milk Protein Concentrate Powder upon Aging: Effect on Solubility. Journal of Agricultural and Food Chemistry, 58(13), 7748-7755. doi:10.1021/jf1007055

Haque, E., Bhandari, B. R., Gidley, M. J., Deeth, H. C., \& Whittaker, A. K. (2011). Ageing-induced solubility loss in milk protein concentrate powder: effect of protein conformational modifications and interactions with water. Journal of the Science of Food and Agriculture, 91(14), 2576-2581. doi:10.1002/jsfa.4478

Haque, E., Bhandari, B. R., Gidley, M. J., Deeth, H. C., \& Whittaker, A. K. (2015). Change in molecular structure and dynamics of protein in milk protein concentrate powder upon ageing by solid-state carbon NMR. Food Hydrocolloids, 44, 66-70. doi:10.1016/j.foodhyd.2014.09.022

Haque, E., Whittaker, A. K., Gidley, M. J., Deeth, H. C., Fibrianto, K., \& Bhandari, B. R. (2012). Kinetics of enthalpy relaxation of milk protein concentrate powder upon ageing and its effect on solubility. Food Chemistry, 134(3), 1368-1373. doi:10.1016/j.foodchem.2012.03.034

Havea, P. (2006). Protein interactions in milk protein concentrate powders. International Dairy Journal, 16(5), 415-422. doi:10.1016/j.idairyj.2005.06.005

Hunter, R. J., Hemar, Y., Pinder, D. N., \& Anema, S. G. (2011). Effect of storage time and temperature of milk protein concentrate (MPC85) on the renneting properties of skim milk fortified with MPC85. Food Chemistry, 125(3), 944-952. doi:10.1016/j.foodchem.2010.09.086 
Jeantet, R., Schuck, P., Six, T., Andre, C., \& Delaplace, G. (2010). The influence of stirring speed, temperature and solid concentration on the rehydration time of micellar casein powder. Dairy Science \& Technology, 90(2-3), 225-236. doi:10.1051/dst/2009043

Jimenezflores, R., \& Kosikowski, F. V. (1986). Properties of ultrafiltered skim milk retentate powders. Journal of Dairy Science, 69(2), 329-339.

Kher, A., Udabage, P., McKinnon, I., McNaughton, D., \& Augustin, M. A. (2007). FTIR investigation of spray-dried milk protein concentrate powders. Vibrational Spectroscopy, 44(2), 375-381. doi:10.1016/j.vibspec.2007.03.006

Le, T. T., Bhandari, B., \& Deeth, H. C. (2011). Chemical and Physical Changes in Milk Protein Concentrate (MPC80) Powder during Storage. Journal of Agricultural and Food Chemistry, 59(10), 5465-5473. doi:10.1021/jf2003464

Le, T. T., Bhandari, B., Holland, J. W., \& Deeth, H. C. (2011). Maillard Reaction and Protein CrossLinking in Relation to the Solubility of Milk Powders. Journal of Agricultural and Food Chemistry, 59(23), 12473-12479. doi:10.1021/jf203460z

Le, T. T., Holland, J. W., Bhandari, B., Alewood, P. F., \& Deeth, H. C. (2013). Direct evidence for the role of Maillard reaction products in protein cross-linking in milk powder during storage. International Dairy Journal, 31(2), 83-91. doi:10.1016/j.idairyj.2013.02.013

Leinberger, D. (2006). Temperature and humidity in ocean containers. In (Proceedings of Dimensions. International Safe Transit Association: East Lansing ed.). USA: Proceedings of Dimensions. International Safe Transit Association: East Lansing.

Marella, C., Salunke, P., Biswas, A. C., Kommineni, A., \& Metzger, L. E. (2015). Manufacture of modified milk protein concentrate utilizing injection of carbon dioxide. Journal of Dairy Science, 98(6), 3577-3589. doi:10.3168/jds.2014-8946

Martins, S., Jongen, W. M. F., \& van Boekel, M. (2000). A review of Maillard reaction in food and implications to kinetic modelling. Trends in Food Science \& Technology, 11(9-10), 364-373. doi:10.1016/s0924-2244(01)00022-x

Masters, k. (2002). Spray Drying in Practice. Paper presented at the Spray Dry Consult International ApS, Charlottenlund, Denmark.

Mimouni, A., Deeth, H. C., Whittaker, A. K., Gidley, M. J., \& Bhandari, B. R. (2010a). Investigation of the microstructure of milk protein concentrate powders during rehydration: Alterations during storage. Journal of Dairy Science, 93(2), 463-472. doi:10.3168/jds.2009-2369

Mimouni, A., Deeth, H. C., Whittaker, A. K., Gidley, M. J., \& Bhandari, B. R. (2010b). Rehydration of high-protein-containing dairy powder: Slow- and fast-dissolving components and storage effects. Dairy Science \&amp; Technology, 90(2-3), 335-344. doi:10.1051/dst/2010002

Nasser, S., Jeantet, R., De-Sa-Peixoto, P., Ronse, G., Nuns, N., Pourpoint, F., . . Delaplace, G. (2017). Microstructure evolution of micellar casein powder upon ageing: Consequences on rehydration dynamics. Journal of Food Engineering, 206, 57-66. doi:10.1016/j.jfoodeng.2017.03.004

Noyes, A., \& Whitney, W. (1897). The rate of solution of solid substances in their own solutions. Journal of the American Chemical Society, 19(12), 930-934.

Oliveira, F., Sousa-Gallagher, M. J., Mahajan, P. V., \& Teixeira, J. A. (2012). Evaluation of MAP engineering design parameters on quality of fresh-sliced mushrooms. Journal of Food Engineering, 108(4), 507-514. doi:10.1016/j.jfoodeng.2011.09.025

Paracha, G. M. U. (2011). Characterisation of the rehydration of milk protein concentrates in the presence of sugar. ( $\mathrm{PhD}$ Thesis), Massey University, Manawatu campus,

Pierre, A., Fauquant, J., Legraet, Y., Piot, M., \& Maubois, J. L. (1992). Native micellar casein separation through cross flow membrane microfiltration. Lait, 72(5), 461-474.

Richard, B., Le Page, J. F., Schuck, P., Andre, C., Jeantet, R., \& Delaplace, G. (2013). Towards a better control of dairy powder rehydration processes. International Dairy Journal, 31(1), 18 28. doi:10.1016/j.idairyj.2012.07.007

Richard, B., Toubal, M., Le Page, J.-F., Nassar, G., Radziszewski, E., Nongaillard, B., . . . Delaplace, G. (2012). Ultrasound tests in a stirred vessel to evaluate the reconstitution ability of dairy powders. Innovative Food Science \& Emerging Technologies, 16, 233-242. doi:10.1016/j.ifset.2012.06.007 
Schuck, Piot, M., Méjean, S., Le Graet, Y., Fauquant, J., Brulé, G., \& Maubois, J. L. (1994). Déshydratation par atomisation de phosphocaséinate natif obtenu par microfiltration sur membrane. Le lait, 74(5), 375-388.

Schuck, P., Jeantet, R., \& Dolivet, A. (2012). Analytical Methods for Food and Dairy Powders: John Wiley \& Sons.

Schuck, P., Mejean, S., Dolivet, A., Beaucher, E., \& Famelart, M. H. (2005). Pump amperage: a new method for monitoring viscosity of dairy concentrates before spray drying. Lait, 85(4-5), 361367. doi:10.1051/lait:2005014

Schuck, P., Mejean, S., Dolivet, A., Gaiani, C., Banon, S., Scher, J., \& Jeantet, R. (2007). Water transfer during rehydration of micellar casein powders. Lait, 87(4-5), 425-432. doi:10.1051/lait:2007016

Selomulya, C., \& Fang, Y. (2013). Food powder rehydration. In B. Bhandari, N. Bansal, M. Zhang, \& P. Schuck (Eds.), Handbook of Food Powders: Processes and Properties (pp. 379-408). Cambridge: Woodhead Publ Ltd.

Sikand, V., Tong, P. S., Walker, J., Wang, T., \& Rodriguez-Saona, L. E. (2016). Short communication: Effect of storage temperature on the solubility of milk protein concentrate 80 (MPC80) treated with $\mathrm{NaCl}$ or KCl. Journal of Dairy Science, 99(3), 1791-1795. doi:10.3168/jds.2015-10158

Singh, H. (2002). Milk Proteins : Functional properties. Encyclopedia of Dairy Science(InH. Roginski (ed.)), 1976-1982.

Snoeren, T. H. M., Dammam, A. J., \& Klok, H. J. (1982). The viscosity of whole milk concentrates. Neth. Milk Dairy J, 36, 305-316.

Udabage, P., Puvanenthiran, A., Yoo, J. A., Versteeg, C., \& Augustin, M. A. (2012). Modified water solubility of milk protein concentrate powders through the application of static high pressure treatment. Journal of Dairy Research, 79(1), 76-83. doi:10.1017/s0022029911000793 
Figure 1. (A) Pictures of $M C P 1$ and visualisation of browning of powder during storage (B) Browning index as a function of storage time for MC $\mathrm{P} 1$ stored at different temperatures

A.

B.

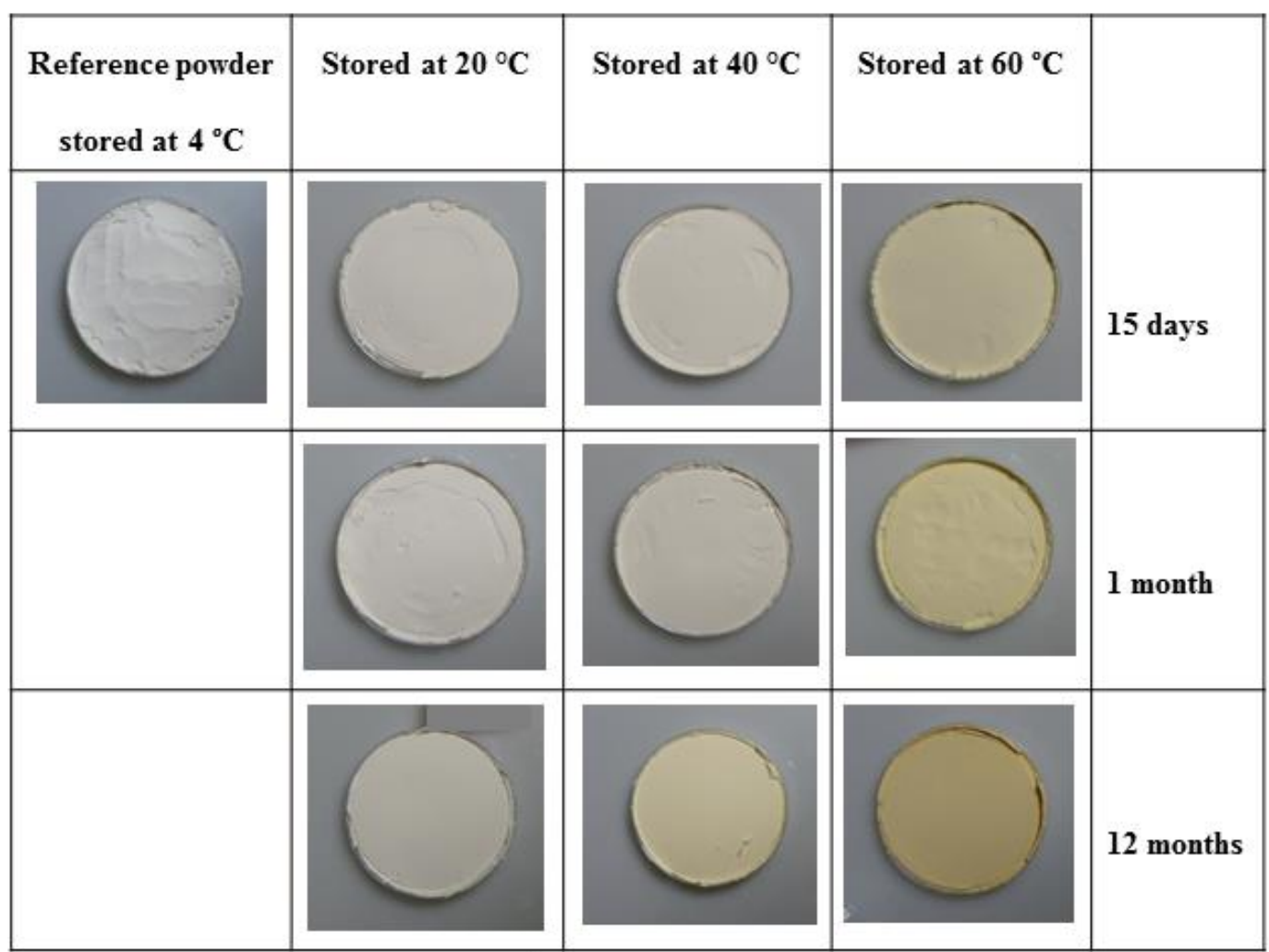

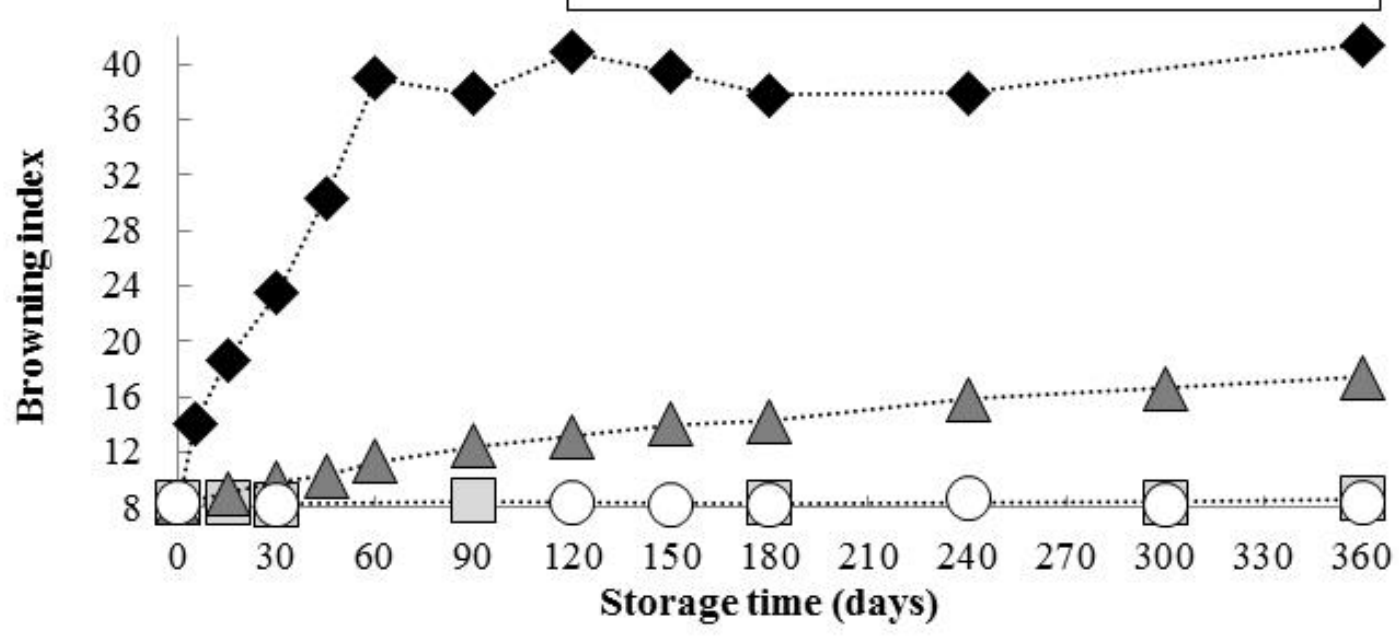

Figure 1. (A) Pictures of MC P1 and visualisation of browning of powder during storage (B) Browning index as a function of storage time for MCP1 stored at different temperatures 
Figure 2. Change in solubility as a function of storage time for MC P1 stored at different temperatures

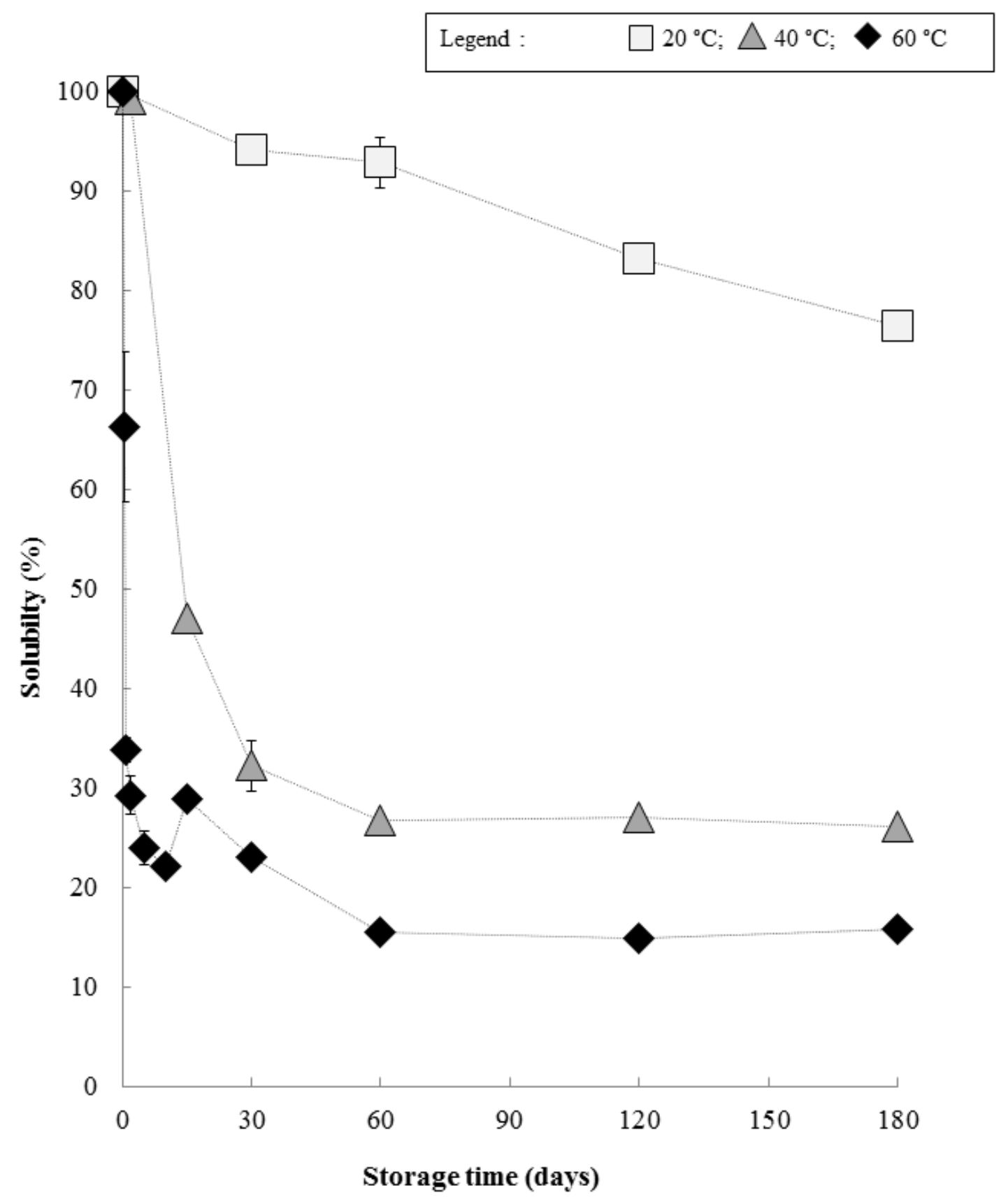

Figure 2. Change in solubility as a function of storage time for MC P1 stored at different temperatures 
Figure 3. Fragmentation time as a function of storage time for $M C P 1$ stored at different temperatures

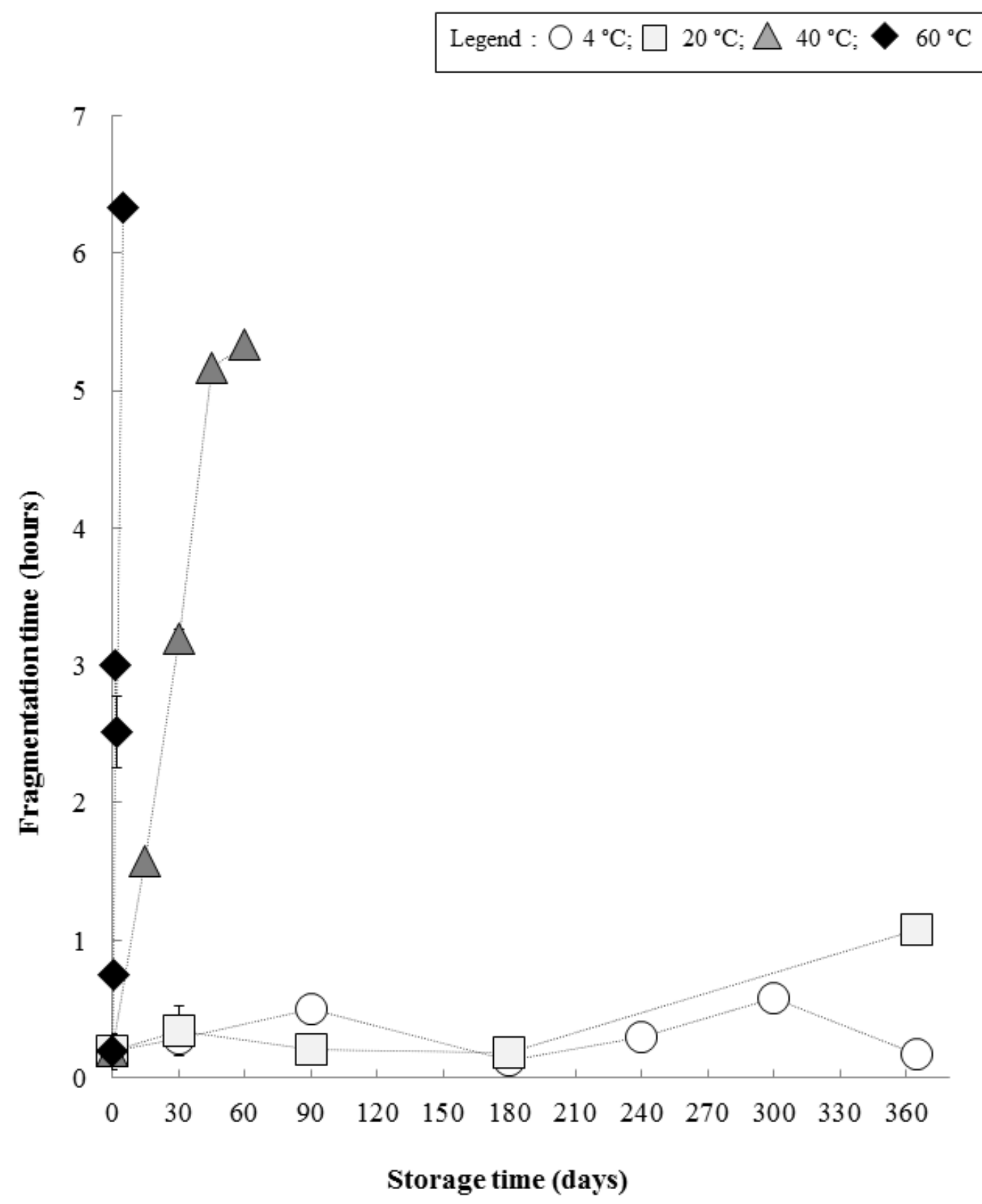

Figure 3. Fragmentation time as a function of storage time for MC P1 stored at different temperatures 
Figure 4. Rehydration time as a function of storage time for MC P1 stored at different temperatures

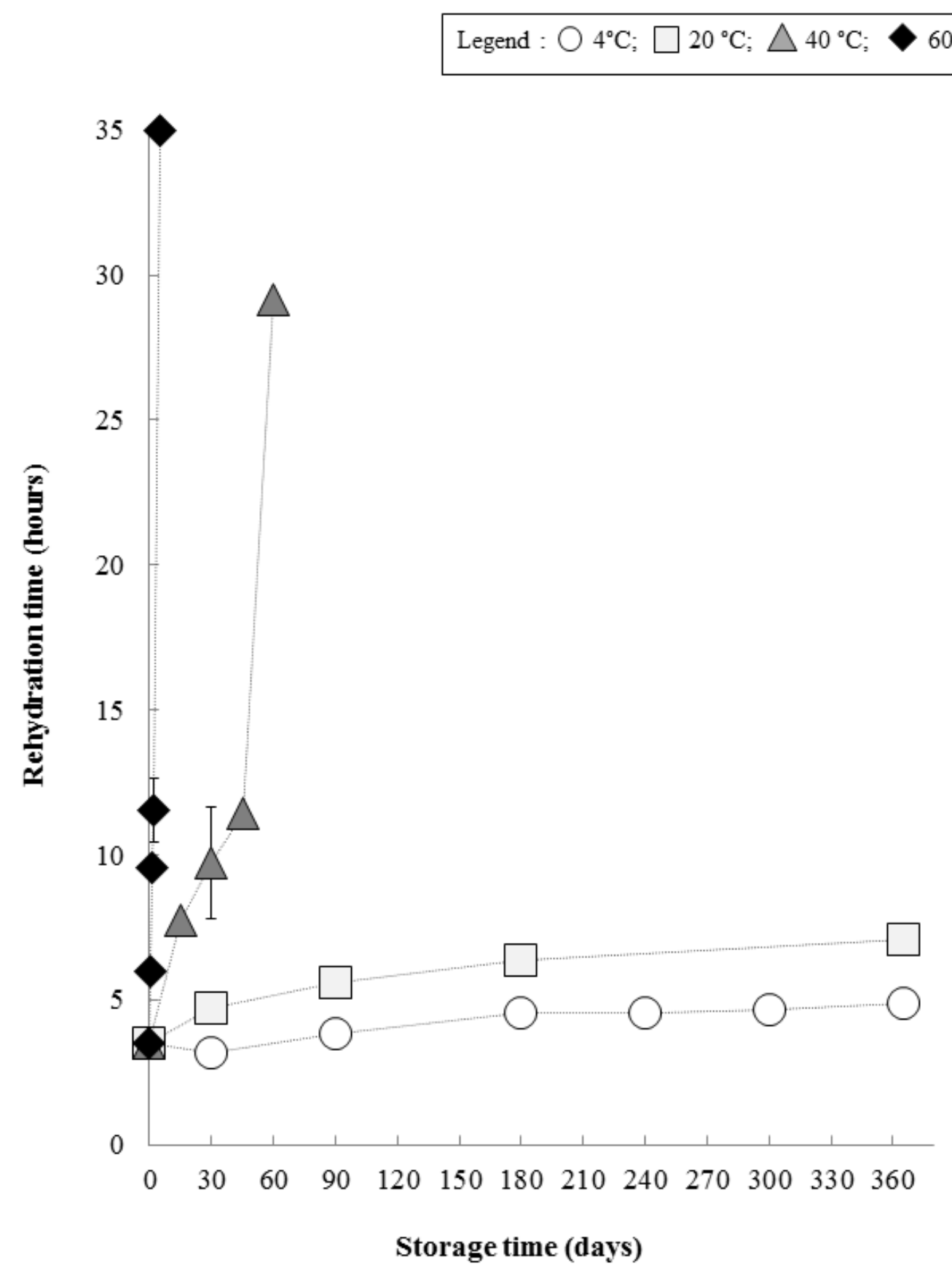

Figure 4. Rehydration time as a function of storage time for MC P1 stored at different temperatures 
Figure 5. Rehydration time as a function of (A) solubility (B) fragmentation time (C) browning index, of MC P1 stored at $4{ }^{\circ} \mathrm{C}$ (circle), $20^{\circ} \mathrm{C}$ (square), $40^{\circ} \mathrm{C}$ (triangle) and $60^{\circ} \mathrm{C}$ (diamond shape); For the legend, the darker the inner colour of the symbol, the longer the storage time.

Reference ageing curves using all ageing points tested are in solid lines, approximate ageing curves established with 3 ageing points (surrounded in red) are in dotted line. Ageing similarities between severe storage and moderate storage are outlined in blue.
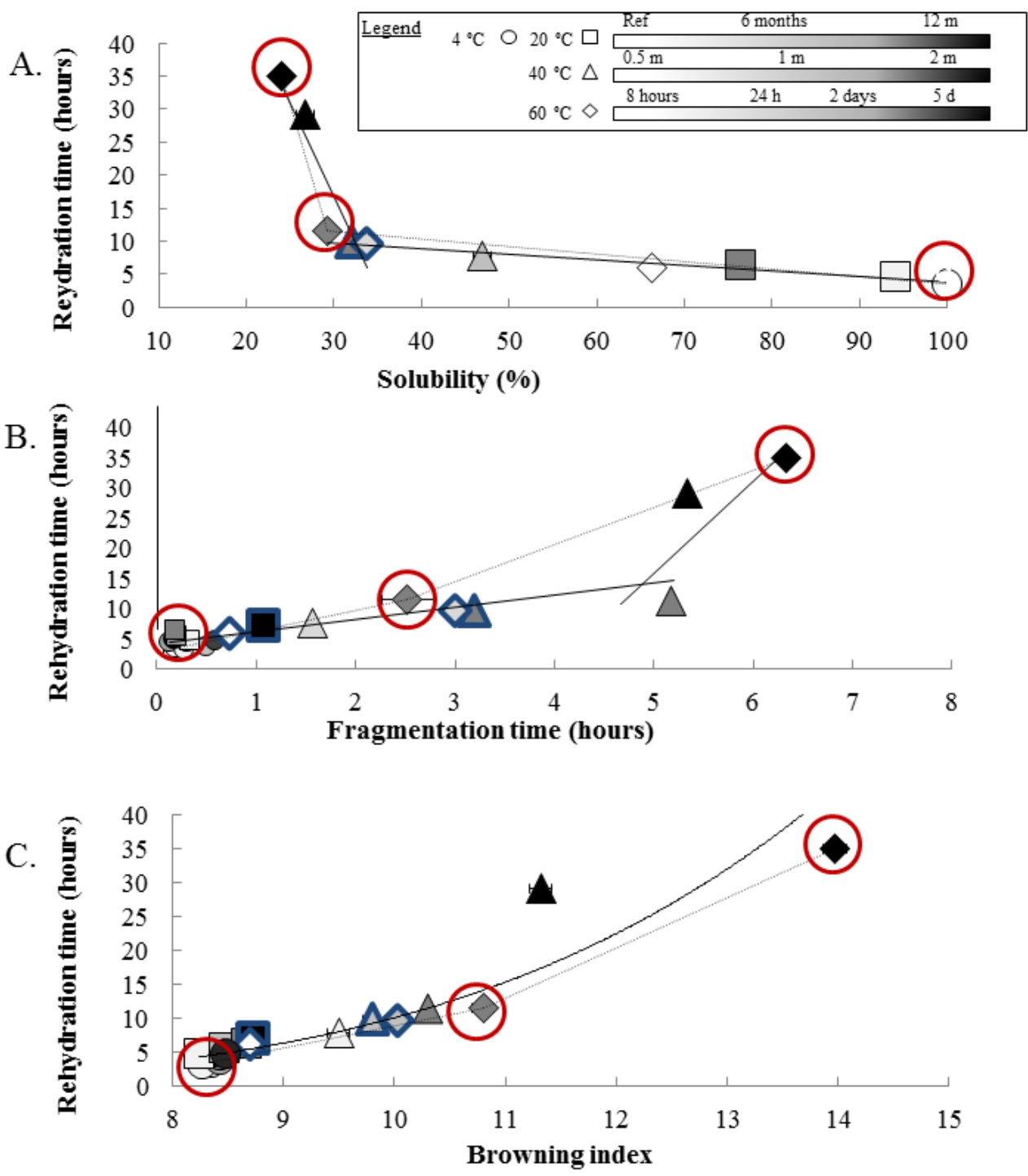

Figure 5. Rehydration time as a function of (A) solubility (B) fragmentation time (C) browning index, of MC P1 stored at $4{ }^{\circ} \mathrm{C}$ (circle), $20^{\circ} \mathrm{C}$ (square), $40^{\circ} \mathrm{C}$ (triangle) and $60^{\circ} \mathrm{C}$ (diamond shape); For the legend, the darker the inner colour of the symbol, the longer the storage time.

Reference ageing curves using all ageing points tested are in solid lines, approximate ageing curves established with 3 ageing points (surrounded in red) are in dotted line. Ageing similarities between severe storage and moderate storage are outlined in blue. 
Figure 6. Rehydration time as a function of (A) solubility (B) fragmentation time (C) browning index, of $\mathrm{MC} \mathrm{P} 2$ stored at $4^{\circ} \mathrm{C}$ (circle), $20^{\circ} \mathrm{C}$ (square), $40{ }^{\circ} \mathrm{C}$ (triangle) and $60^{\circ} \mathrm{C}$ (diamond shape); ); For the legend, the darker the inner colour of the symbol, the longer the storage time.

Ageing curves using whole ageing points are in solid lines, ageing curves established with 3 ageing points (surrounded in red) are in dotted line. Ageing similarities between severe storage and moderate storage are outlined in blue
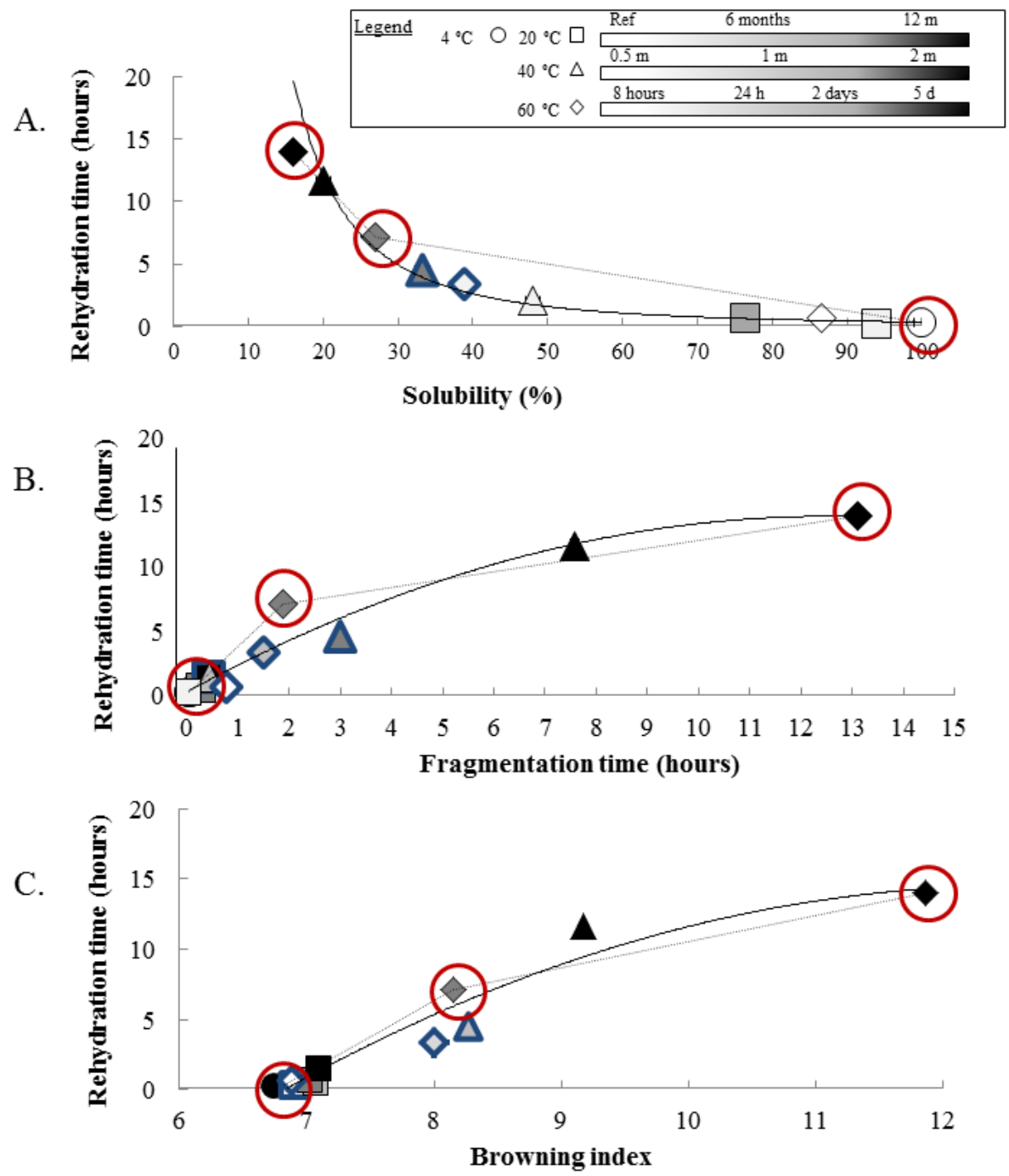

Figure 6. Rehydration time as a function of (A) solubility (B) fragmentation time (C) browning index, of MC P2 stored at $4^{\circ} \mathrm{C}$ (circle), $20^{\circ} \mathrm{C}$ (square), $40^{\circ} \mathrm{C}$ (triangle) and $60^{\circ} \mathrm{C}$ (diamond shape); ); For the legend, the darker the inner colour of the symbol, the longer the storage time.

Ageing curves using whole ageing points are in solid lines, ageing curves established with 3 ageing points (surrounded in red) are in dotted line. Ageing similarities between severe storage and moderate storage are outlined in blue 
Figure 7. Comparison between rehydration times experimentally measured and predicted using approximate ageing curves based on the measurements of (A) solubility (B) fragmentation time (C) browning index. Measurements for MC P1 are in dark, measurements for MC P2 are in grey, measurements for samples going through storage accidents are represented by red cross. Dotted line represent percentage error.
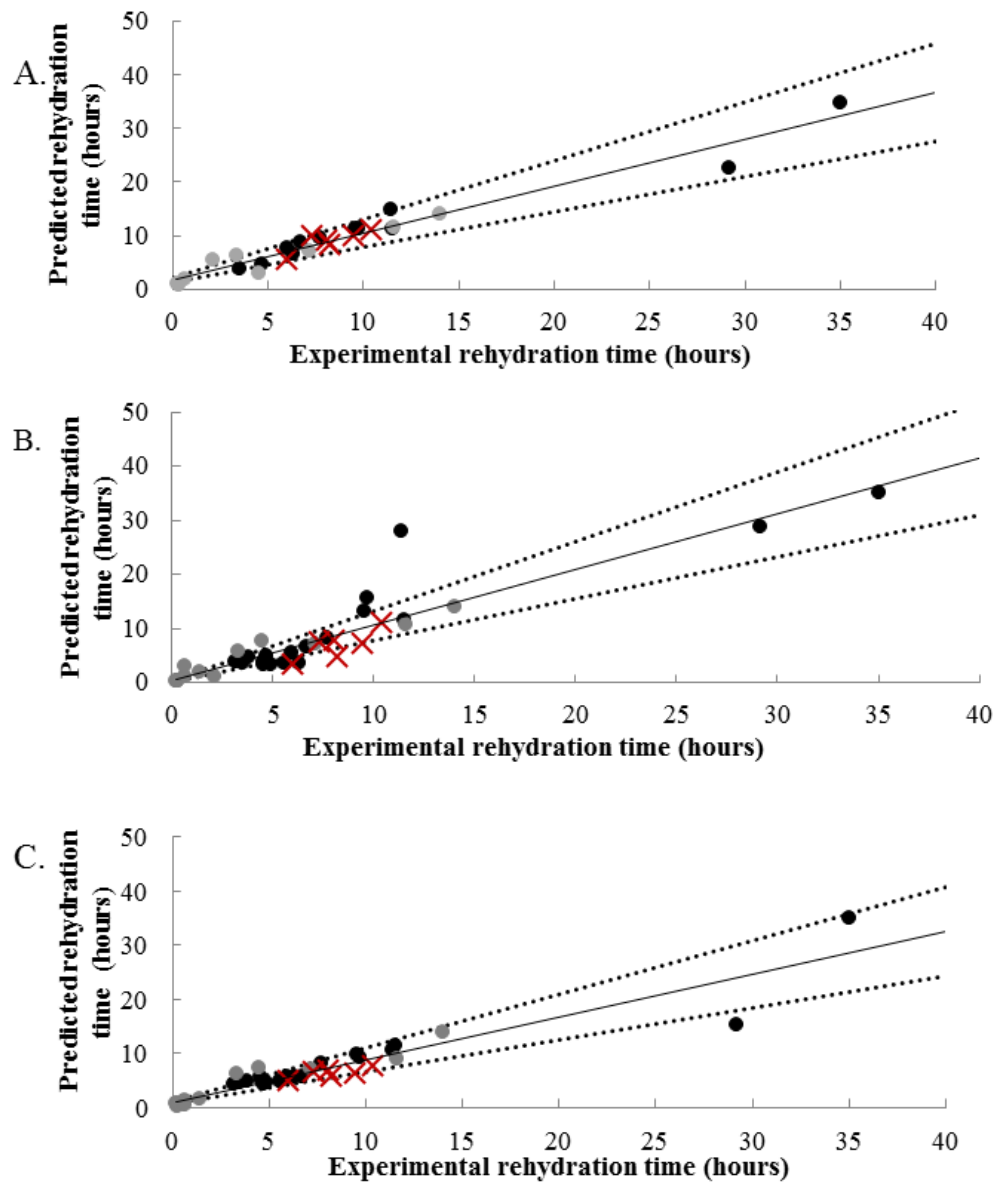

Figure 7. Comparison between rehydration times experimentally measured and predicted using approximate ageing curves based on the measurements of (A) solubility (B) fragmentation time (C) browning index Measurements for MC P1 are in dark, measurements for MC P2 are in grey, measurements for samples going through storage accidents are represented by red cross. Dotted line represent percentage error. 
Table 1. Physico chemical properties of MC retentates and powders

\begin{tabular}{|c|c|c|c|c|c|c|c|c|}
\hline & $\begin{array}{c}\text { Total dry } \\
\text { matter } \\
\left(\mathrm{g} \cdot \mathrm{kg}^{-1}\right)\end{array}$ & $\begin{array}{l}\text { Total nitrogen } \\
(\% \mathrm{~N} \times 6.38)\end{array}$ & $\begin{array}{l}\text { Non Protein } \\
\text { Nitrogen } \\
(\% \mathrm{~N} \times 6.38)\end{array}$ & $\begin{array}{c}\text { Non Casein } \\
\text { Nitrogen } \\
(\% \mathrm{~N} \times 6.38)\end{array}$ & $\begin{array}{c}\text { Ash } \\
\left(\mathrm{g} \cdot \mathrm{kg}^{-1}\right)\end{array}$ & $\begin{array}{l}\text { Lactose } \\
\left(\mathrm{g} \cdot \mathrm{kg}^{-1}\right)\end{array}$ & $\begin{array}{c}\text { Particle } \\
\text { size }(\mu \mathrm{m}) \\
\text { Dv50 }\end{array}$ & $\begin{array}{l}\text { Water } \\
\text { activity }\end{array}$ \\
\hline \multicolumn{9}{|c|}{ Batch 1} \\
\hline Retentate 1 & 137.60 & 11.9 & 0.01 & 1.16 & 11.00 & & & \\
\hline Powder 1 & 944.40 & 81.55 & 1.02 & 7.43 & 81.49 & 25.50 & 53.51 & 0.25 \\
\hline \multicolumn{9}{|c|}{ Batch 2} \\
\hline Retentate 2 & 125.00 & 11.10 & 0.01 & 1.03 & 10.00 & & & \\
\hline Powder 2 & 935.00 & 83.60 & 0.97 & 7.05 & 75.20 & 11.30 & 39.01 & 0.29 \\
\hline
\end{tabular}


Table 2. Functional properties of the two powders studied at reference state (storage at $4^{\circ} \mathrm{C}$ ) and after 5 days' storage at $60{ }^{\circ} \mathrm{C}$

\begin{tabular}{|c|c|c|c|c|}
\hline & \multicolumn{2}{|c|}{ Powder 1 } & \multicolumn{2}{c|}{ Powder 2 } \\
\hline & $\begin{array}{c}\text { Reference } \\
\text { powder }\end{array}$ & $\begin{array}{c}\text { Powder stored 5 days } \\
\text { at } 60^{\circ} \mathrm{C}\end{array}$ & $\begin{array}{c}\text { Reference } \\
\text { powder }\end{array}$ & $\begin{array}{c}\text { Powder stored 5 days at } \\
60{ }^{\circ} \mathrm{C}\end{array}$ \\
\hline Browning index & 8.34 & 13.97 & 6.82 & 11.86 \\
\hline $\begin{array}{c}\text { Solubility (\%) } \\
\text { Fragmentation time } \\
\text { (Hours) }\end{array}$ & 100.00 & 24.00 & 100.00 & 16.10 \\
\hline $\begin{array}{c}\text { Rehydration time } \\
\text { (Hours) }\end{array}$ & 3.51 & 6.33 & 0.04 & 13.10 \\
\hline
\end{tabular}

